\title{
Physiological behavior of Campomanesia xanthocarpa O. Berg. seedlings under flooding and shading
}

\section{Comportamento fisiológico de mudas de Campomanesia xanthocarpa O. Berg. sob inundação e sombreamento}

\author{
Maílson Vieira Jesus ${ }^{1 *}$; Silvana de Paula Quintão Scalon²; Daiane Mugnol Dresch; \\ Jéssica Aline Linnéz; Lucas Coutinho Reis ${ }^{3}$
}

\section{Highlights}

The sum of flooding and $70 \%$ shading conferred stressful condition to C. xanthocarpa.

The seedlings adjustment was favorable over the 45 days of flooding under $70 \%$ shade.

The better seedlings responses to flooding were with $30 \%$ shade.

The photosynthetic rate was the main factor regulator of seedling responses.

\section{Abstract}

Physiological information about native species, make it possible to know their potential for use in programs to recovery degraded areas. Nowadays climate changes are severe and factors as water and light are involved with plant development and growth. We hypothesized that shading may contribute to adjusting the characteristics of photosynthetic metabolism of Campomanesia xanthocarpa seedlings under flooding. Thus, this work aimed to evaluate the flooding times and shading levels for gas exchanges and the maximal photochemical efficiency of PSII (Fv/Fm) in C. xanthocarpa seedlings. Seedlings were grown under two water regimes (control and flooding), three levels of shading $(0,30$, and $70 \%$ ) and 4 evaluation periods $(0,15,30$, and 45 days). We verified damages to the photosynthetic apparatus and reductions in the efficiency of the photochemical process under flooding and at a high level of shading (70\%) in a short period (15 days). However, seedlings showed favourable responses to the adjustment over the 45 days of exposure to those conditions. According to the multivariate analysis, it was possible to identify the relation between photosynthetic rate and stomatal conductance as the main factor of metabolic adjustments in the tolerance of $C$. xanthocarpa to flooding and high shading intensity. $C$. xanthocarpa was more sensitive

1 Drs. in Agronomy, Universidade Federal da Grande Dourados, UFGD, Faculty of Agrarian Sciences, Dourados, MS, Brazil. E-mail: mvjagro@gmail.com; daiamugnol@hotmail.com;

2 Profa Dra, Graduate Program in Agronomy, UFGD, Faculty of Agrarian Sciences, Dourados, MS, Brazil. E-mail: silvanascalon@ufgd.edu.br;

${ }^{3}$ Doctoral Students, Graduate Program in Agronomy, UFGD, Faculty of Agrarian Sciences, Dourados, MS, Brazil. E-mail: jessica.aline.linne@gmail.com; lucasc_reis@hotmail.com.

* Author for correspondence

Received: Mar. 15, 2021 - Approved: July 28, 2021 
to short periods of flooding conditions and full sun and high level of shading (70\%), however, it presented better adjustment responses to flooding periods when associated with $30 \%$ shade.

Key words: Guabiroba tree. Gas exchanges. Stress. Native fruit.

\section{Resumo}

As informações fisiológicas sobre as espécies nativas, possibilitam conhecer seu potencial para uso em programas de recuperação de áreas degradadas. As mudanças climáticas são comuns e fatores como água e luz estão envolvidos no desenvolvimento e crescimento das plantas. Nossa hipótese é que o sombreamento pode contribuir para ajustar as características do metabolismo fotossintético de mudas de gabiroba-de-árvore (Campomanesia xanthocarpa) em alagamento. Assim, este trabalho teve como objetivo avaliar os tempos de alagamento e níveis de sombreamento sobre as trocas gasosas e na eficiência fotoquímica máxima do PSII (Fv/Fm) em mudas de C. xanthocarpa. As mudas foram cultivadas em dois regimes hídricos (controle e alagamento), três níveis de sombreamento (0, 30 e 70\%) e quatro épocas de avaliação $(0,15,30$ e 45 dias). Verificou-se danos ao aparato fotossintético e reduções na eficiência do processo fotoquímico em alagamento e com alto nível de sombreamento (70\%) por curto período (15 dias). No entanto, as mudas apresentaram respostas favoráveis de ajuste ao longo dos 45 dias de exposição nessas condições. Pela análise multivariada, foi possível identificar a relação entre a taxa fotossintética e a condutância estomática como principais fatores de ajustes metabólicos na tolerância de C. xanthocarpa ao alagamento e alta intensidade de sombreamento. C. xanthocarpa foi mais sensível nos curtos períodos de alagamento quando associada a pleno sol e ao maior sombreamento (70\%). Porém, apresentou melhores respostas de ajuste aos períodos de alagamento quando associada a $30 \%$ de sombra.

Palavras-chave: Guabirobeira. Trocas gasosas. Estresse. Fruta nativa.

\section{Introduction}

The recent global climate changes are marked by increased flood due to seasonality in above-average rainfall (Fan et al., 2014; Posada-Casierra \& Cutler, 2017). According to Lüttge (2004), the second factor that affects the growth, production and survival of plants is the light. When those factors are associated, both in stressful levels, may cause irreversible damages to plants. Thus, to explain the plasticity that a species has under environmental stress, experimentation with analysis of physiological processes related to chlorophyll a fluorescence and gas exchanges can provide information in a fast and safe way, as the species with potential use in agroforestry systems and programs of degraded area recovery fit these conditions (Baker \& Rosenqvist, 2004; Calatayud, Roca, \& Martínez, 2006).

In this context, Campomanesia xanthocarpa Mart. ex O. Berg (Myrtaceae) shows up as an endemic species with occurrences in Brazil, Argentina, Paraguay and Uruguay. It is known popularly as "gabirobeira", whose fruits are widely consumed by the local population and birdlife. This species has great amounts of vitamins, fibers and micronutrients. It has been studied extensively for its medicinal properties (anti-inflammatory, antiplatelet, antidiabetic) found in all the parts of these plants. (Lorenzi, 2008; Duarte, Dias, Melo Pereira, Gervásio, \& Schwan, 2009; Khurana, Venkataraman, \& Hollingsworth, 
2013; Viecili et al., 2014; Lescano et al., 2016; Souza et al., 2017; Otero et al., 2017).

Some studies with Campomanesia species indicated different responses according to light availability. Krupek and Lima (2012) observed leaves morphoanatomical variations in C. xanthocarpa. In C. adamantium (Ajalla, Vieira, Volpe, \& Zárate, 2014) and in C. xanthocarpa (Bartieres et al., 2020) was observed greater growth and photosynthetic metabolism, respectively, under shading compared to seedlings cultivated in full sun.

Regarding luminous availability, Pimenta (1998), in his classic work with C. xanthocarpa, carried outasurveyofthespecies' population behavior, one of the approaches being tolerance to flooding. Lemos-Filho (2000) observed that the seedlings of two Myrtaceae species (Eugenia dysenterica and Campomanesia adamantium) showed greater efficiency of the photosynthetic apparatus in the rainy season compared to the dry season. However, the water deficit in combination with high levels of irradiance caused a significant reduction in the maximal photochemical efficiency of photosystem II.

However, no studies about the interaction between luminous availability and flooding were found about C. xanthocarpa, which amplifies its effects and increases the opportunity for greater knowledge about the responses, tolerance, adaptation and potential use of the species for recovery of gallery forests, as well as better conditions for seedling production. The interactive effect of light and water stresses in plants, i.e., under flooding, has been studied for some native trees, but has not been extensively investigated (Cremon, Scalon, Rosa, \& Dresch, 2020). We hypothesized that shading may contribute to adjusting the characteristics of photosynthetic metabolism of C. xanthocarpa seedlings under flooding. Thus, this work aimed to evaluate the flooding times and shading levels for the gas exchanges and the maximal photochemical efficiency of PSII (Fv/ Fm) in C. xanthocarpa seedlings.

\section{Materials and Methods}

Study area, treatments and experimental design

The experiment was carried out at the plant nursery from Agrarian Sciences Faculty at the Federal University of Grande Dourados (UFGD), in Dourados city - MS in 2018. Mature fruits of Campomanesia xanthocarpa were collected from natural populations (Ministério do Meio Ambiente [MMA], 2018), in the Itamarati Settlement, Ponta Porã (MS) (Figure 1A-B), in which the species was identified and the exsiccate was deposited in the Herbarium, UFGD (DDMS), under number 4644. For seedling propagation, sowing was done in 72-cell expanded polystyrene trays filled with commercial substrate (Tropstrato ${ }^{\circledR}$ ). A completely randomized design was used, organized in a split-split plot scheme, corresponding the plot 2 water regimes (control and flooding), the subplot 3 levels of shading $(0,30$ and $70 \%)$ and the sub-subplot 4 evaluation periods $(0,15,30$ and 45 days), with 4 repetitions. The experimental unit was compound by a plastic pot containing two C. xanthocarpa seedlings with 180 days of age. Seedlings underwent acclimatization to the different luminous environments for 10 days and then they were submitted to water regimes. 
(a)

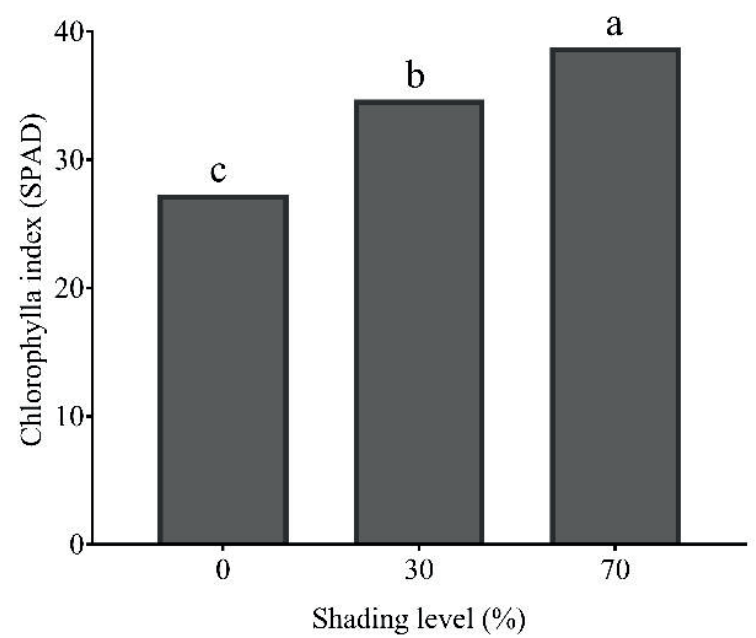

(c)

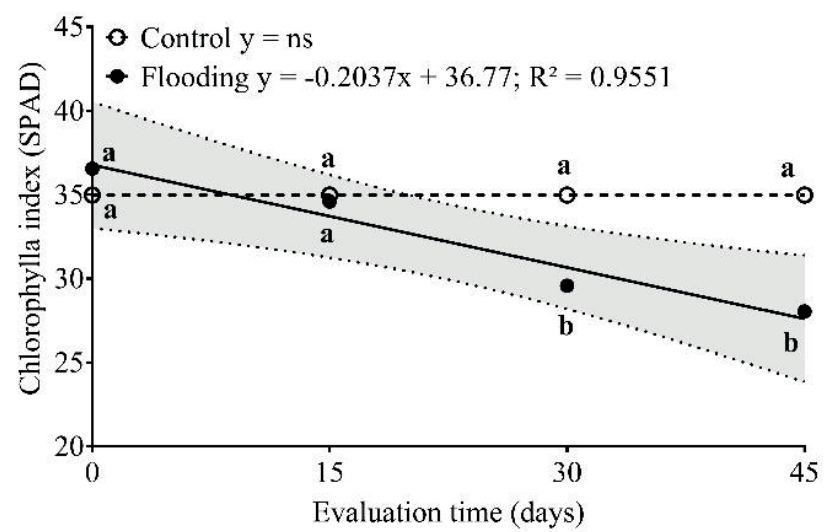

(b)

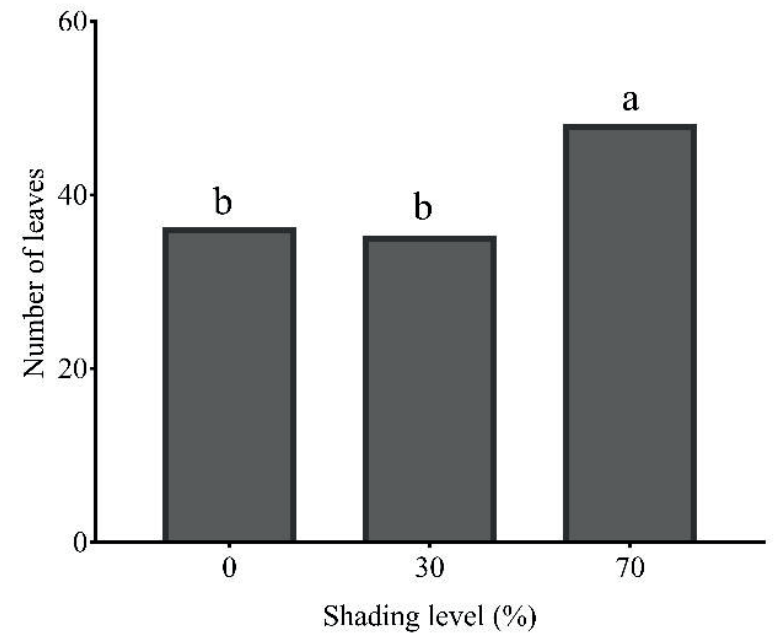

(d)

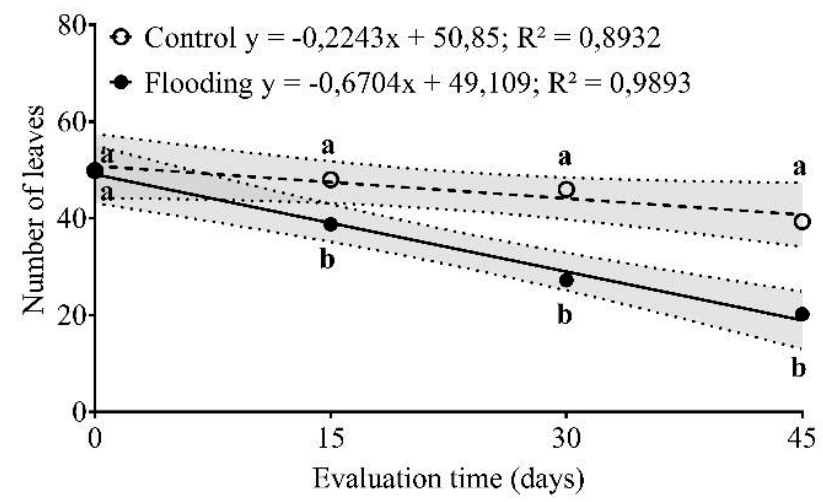

Figure 1. Chlorophyll index (a) and number of leaves (b) in Campomanesia xanthocarpa Berg seedlings. submitted to flooding and shading. Means followed by distinct letters differ from each other by the Tukey test ( $p \geq 0.05$ ). Chlorophyll index (c) and number of leaves (d) in seedlings of Campomanesia xanthocarpa Berg. according to the period of flooding. Means followed by distinct letters differ from each other by the Bonferroni t-test $(p \geq 0.05)$. The area fill shows the $95 \%$ confidence bands. ns = not significant.

In order to simulate the flooding, the potted seedlings were flooded $5.0 \mathrm{~cm}$ above the soil surface in a plastic tank. The substrate to fill the 7-litre capacity pots consisted in a mixture in the ratio 2:1 (v:v) of Dystroferric Red Latosol and medium sand, respectively. The control seedlings were irrigated to maintain $75 \%$ of water retention capacity in the substrate. Black nylon screens (Sombrite ${ }^{\circledR}$ ) provided the shading.

Climatic data were obtained by a thermo-hygrometer device. In the flooding phase in up to 45 days, we verified average temperatures and relative humidity, 
respectively, of $36.8^{\circ} \mathrm{C}$ and $37.5 \% \mathrm{RH}$ under $0 \%$ shading (full sun), $34.1^{\circ} \mathrm{C}$ and $45,8 \%$ under $30 \%$ shading and $33.2^{\circ} \mathrm{C}$ and $53.7 \%$ under $70 \%$ shading.

\section{Characteristics evaluated}

The control seedlings were evaluated in the same periods as seedlings under flooding. In addition to the survival percentage, following characteristics were evaluated:

\section{The Clorophyll index (SPAD), number of leaves and the maximal photochemical efficiency of $P S I I(F V / F m)$}

The chlorophyll index was obtained by a chlorophyll analyzer (Konica Minolta - SPAD 502) and Fv/Fm (on dark-adapted leaves for 30 minutes) measured by a portable fluorometer (OS-30p - Opti-Sciences Chlorophyll Fluorometer, Hudson, USA), which both evaluations occured from 08:00 to11:00 am and used completely expanded leaves located on intermediate stem branches.

\section{Photosynthetic characteristics}

Photosynthetic rate $(\mathrm{A})$; leaf transpiration (E); stomatal conductance (gs); internal carbon dioxide (Ci) and carboxylation efficiency of Rubisco (A/Ci) were measured by using an infrared gas analyzer (IRGA, brand ADC, model LCi PRO, Analytical Development Co. Ltd., Hoddesdon, UK). These evaluations were performed having four seedlings per treatment in the morning, from 8 to $11 \mathrm{am}$, in completely expanded leaves which they were previously marked. Then, all the measurements were always carried out on the same leaves, considering only the data measured under photosynthetic photon flux (PPF) greater than $700 \mu \mathrm{mol} \mathrm{m} \mathrm{m}^{-2} \mathrm{~s}^{-1}$.

\section{Water potential $\left(\Psi_{\mathrm{W}}\right)$}

Obtained from individual leaf readings which belonged to the second pair of completely expanded leaves from the apex to the base, using a pressure chamber (Portable Plant water status console - model 3115), right after the leaves collection.

\section{Statistical analysis}

For the analysis of results, means were submitted to analysis of variance and when significant at $5 \%$ by $\mathrm{F}$ test were compared for water regime by Bonferroni's test, shading levels by Tukey test and adjusted by regression equations for times using the statistical software SISVAR 5.3 (Ferreira, 2014). An exploratory analysis on data, according to the parameters evaluated, was applied using the multivariate statistical method, called factorial analysis (FA). The extraction of factors was carried out through principal component analysis (PCA). Software XLSTAT software, version 2019 (AddinSoft) was used for this purpose. All graphics were elaborated in GraphPad Prism software, version 7.00 (GraphPad).

\section{Results and Discussion}

During the evaluations, $100 \%$ of the seedling survival was verified, regardless of the cultivation conditions. 
The chlorophyll index, number of leaves, and the the maximal photochemical efficiency of PSII (Fv/Fm)

Plants submitted to $70 \%$ shading had higher number of leaves and there were no differences between averages from $0 \%$ and $30 \%$ shades (Figure 1b). Seedlings under the highest shading also had the greatest chlorophyll index (Figure 1a).

The results showed significantly higher for the chlorophyll index as higher the shading levels were, indicating an adaptive strategy to these different conditions. Thus, higher pigment contents occurred in order to promote greater light absorption. Exposure to full sun can cause excessive accumulation of excitation energy, which if not dissipated, may cause negative effects, such as cell oxidation (Burritt \& Mackenzie, 2003; Adams, Zarter, Ebbert, \& Demmig-Adams, 2004) leading to the senescence and degradation of chlorophyll (Deng, Cao, Tang, Lu, \& Zhang, 2001). Then, justifying the lowest SPAD index in C. xanthocarpa seedlings under full sun. In this context, the higher pigment contents under $70 \%$ shading were accompanied by higher number of leaves.

During the evaluation times, the number of leaves decreased in both hydric regimes (Figure 1d). However, seedlings under flooding had the lowest values in the evaluation periods after flooding establishment. At 45 days, the proportion in decline for number of leaves between the control and flooded regimes was $20 \%$ and $60 \%$, respectively. This behavior could be expected since, with advancing flooding time, the tendency of leaf abscission to occur increases, which causes a reduction in the number of leaves as observed for other species (Zhao et al., 2014).
The chlorophyll index for control plants did not modify significantly, with a general average of 34.98. However, there was a linear decrease during flooding, which it was lower and varied significantly from control plants only at 30 and 45 days (Figure 1c).

However, under $30 \%$ shading the seedlings showed no differences for the number of leaves compared to the full sun (Figure 1b), indicating an adaptive process, since many plants when shaded leaves tend to have a greater number and more expanded to optimize light absorption. We emphasize that flooding negatively influenced these characteristics (Figure 1d). The reduction in the number of leaves observed after 15 days of flooding can be attributed to the reduction in ion absorption and translocation as mentioned by Marschner (2012).

Control and flooded seedlings under $70 \%$ of shading had a linear decreasing response to Fv/Fm during the evaluation times. However, the responses were lower compared to the others under flood condition, more specifically, from 30 days. Regardless of water regime, plants under $30 \%$ shade increased Fv/Fm response (Figure 2a.1). Under 30\%, the seedlings are in a more favorable condition for photochemical reactions and with the seedling growth, the energy demand increases, which is represented by the increase in Fv/Fm throughout the evaluations. No significance was found at $0 \%$ shading for the period as well as no differences between the regimes (Figure 2a.2). Seedlings may receive much more light under full sun than they can process, leading to a stress condition and consequently to a lower level of photochemical efficiency. 
(a.1)

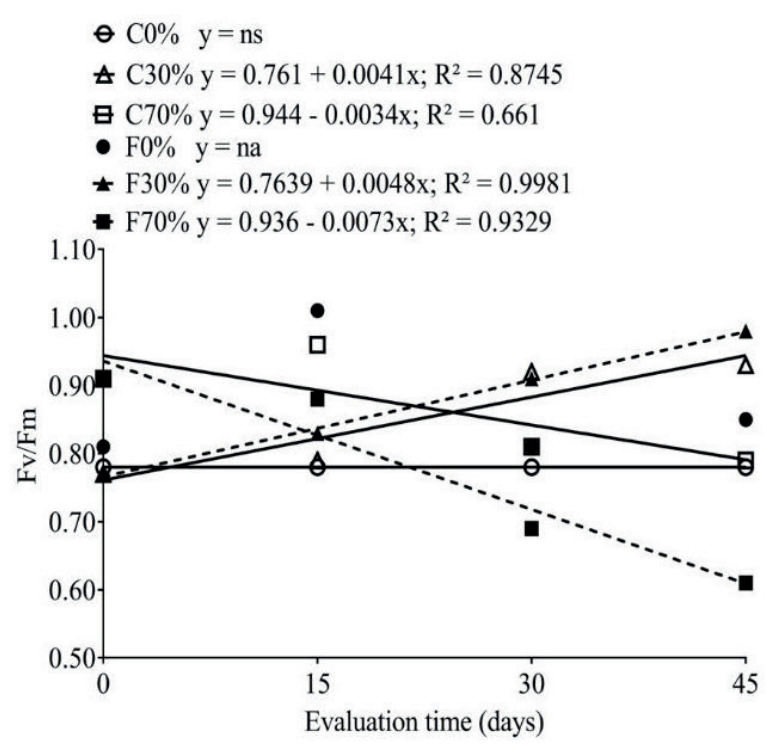

(a.2)

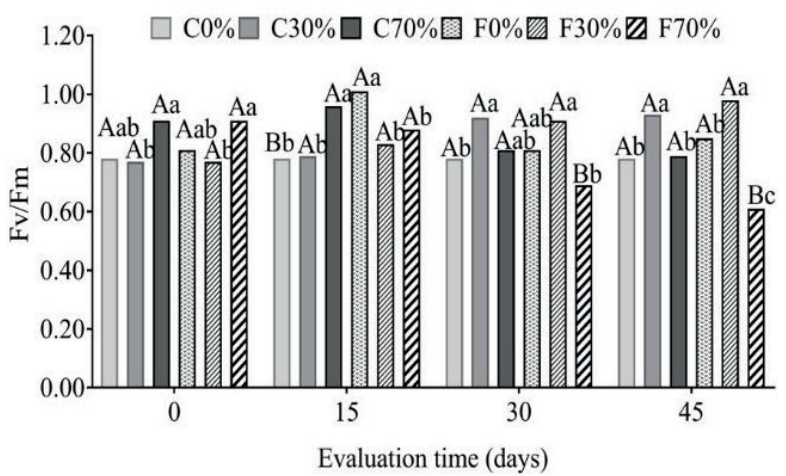

Figure 2. The maximal photochemical efficiency of PSII (a.1, a.2) in Campomanesia xanthocarpa Berg seedlings according to evaluation period, hydric regime (C: control; F: flooding) and shading $(0 \% ; 30 \%$, and $70 \%)$. Equal uppercase letters do not differ from each other for regime at each level of time and shadow by the Bonferroni t-test $(p \geq 0.05)$. Equal lowercase letters do not differ from each other for shading at each time level and regime, by Tukey's test ( $p \geq 0.05)$. ns = not significant; na $=$ not adjusted.

The increase in Fv/Fm under 30\% of shading indicates that C. xanthocarpa seedlings were more efficient in the use of light under this condition and they had an energy loss, in the form of heat and it was more efficient in the regeneration process of rubisco (Baker, 2008; S. Li, Yang, Yang, Chen, \& Ni, 2015), and therefore, increases the carboxylation efficiency culminating with higher photosynthetic rate.

\section{Photosynthetic characteristics}

There were decreases in photosynthetic rate $(A)$, leaf transpiration (E) and stomatal conductance (gs) for all the treatments along the evaluation period. Plants without flood conditions and under $70 \%$ of shade had the highest average at the end of the evaluation (Figure 3a.1 and 3a.2). It is noteworthy, that the photosynthetic rate, although reduced with the evaluation time, remained higher in the control seedlings under shading and the others showed a tendency to adjust and recover values after 30 days. This behavior was similar to that observed for Fv/ Fm and chlorophyll index, which indicates the preference of C. xanthocarpa for a shaded environment. 
(a.1)

${ }^{\theta} \mathrm{C} 0 \% \quad \mathrm{y}=5.35-0.2043 \mathrm{x}+0.0026 \mathrm{x}^{2} ; \mathrm{R}^{2}=0.9719$

$\star \mathrm{C} 30 \% \mathrm{y}=5.408-0.0761 \mathrm{x} ; \mathrm{R}^{2}=0.986$

E $\mathrm{C} 70 \% \mathrm{y}=5.8775-0.0725 \mathrm{x}+0.0009 \mathrm{x}^{2} ; \mathrm{R}^{2}=0.52$

- $\mathrm{F} 0 \% \mathrm{y}=5.605-0.2307 \mathrm{x}+0.0029 \mathrm{x}^{2} ; \mathrm{R}^{2}=0.9721$

A. $F 30 \% y=5.2015-0.2262 x+0.0032 x^{2} ; R^{2}=0.9568$

- $F 70 \% y=6.0775-0.2175 x+0.0023 x^{2} ; R^{2}=0.9964$

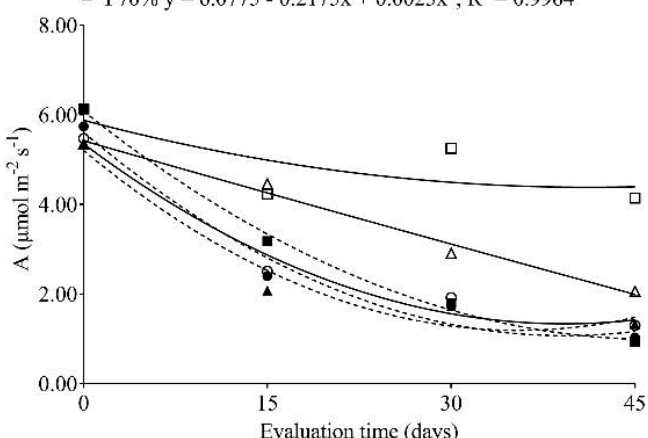

(b.1)

$\theta \mathrm{C} 0 \% \quad \mathrm{y}=3.202-0.0455 \mathrm{x} ; \mathrm{R}^{2}=0.9299$

$\triangle \mathrm{C} 30 \% \mathrm{y}=2.763-0.0481 \mathrm{x} ; \mathrm{R}^{2}=0.6064$

$\forall \mathrm{C} 70 \% \mathrm{y}=2.5845-0.0747 \mathrm{x}+0.0011 \mathrm{x}^{2} ; \mathrm{R}^{2}=0.9882$

- $\mathrm{F} 0 \% \mathrm{y}=3.044-0.1594 \mathrm{x}+0.0025 \mathrm{x}^{2} ; \mathrm{R}^{2}=0.9998$

A. $\mathrm{F} 30 \% \mathrm{y}=2.2805-0.1106 \mathrm{x}+0.0015 \mathrm{x}^{2} ; \mathrm{R}^{2}=0.9799$

- $F 70 \% y=2.533-0.1231 x+0.0017 x^{2} ; R^{2}=0.9951$

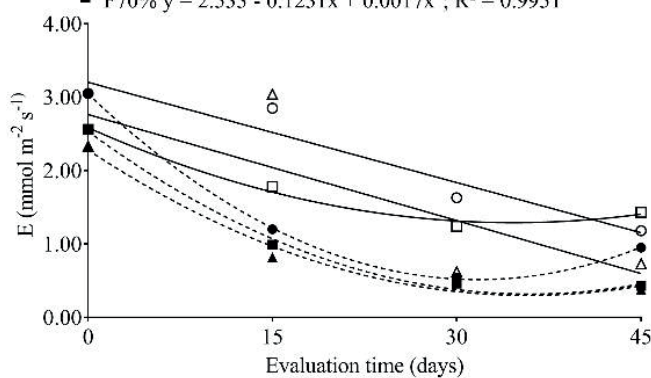

(c.1)

$\theta \mathrm{C} 0 \% \mathrm{y}=0.0829-0.0025 \mathrm{x}+0.00003 \mathrm{x}^{2} ; \mathrm{R}^{2}=0.9998$

$\triangle \mathrm{C} 30 \% \mathrm{y}=0,0694-0,0001 \mathrm{x}-0,00003 \times 2 ; \mathrm{R}^{2}=0.7619$

$\forall \mathrm{C} 70 \% \mathrm{y}=0,0895-0,00003 \mathrm{x}-0,00003 \mathrm{x}^{2} ; \mathrm{R}^{2}=0.9983$

- $\mathrm{F} 0 \% \mathrm{y}=0.0771-0.0041 \mathrm{x}+0.00006 \mathrm{x}^{2} ; \mathrm{R}^{2}=0.9472$

- $F 30 \% y=0.0586-0.0029 x+0.00004 x^{2} ; R^{2}=0.974$

- $F 70 \% y=0,0907-0,0044 x+0,00006 x 2 ; R^{2}=0,9979$

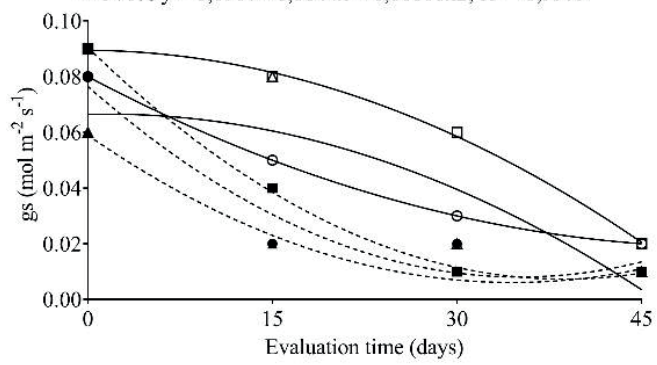

(a.2)

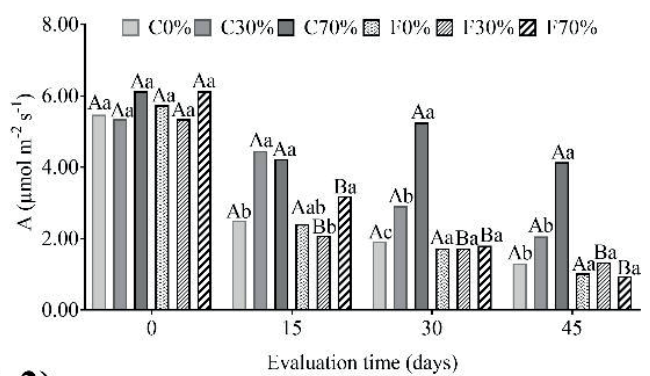

(b.2)

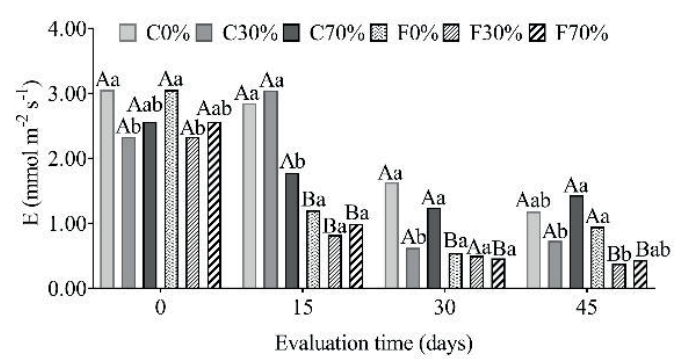

(c.2)

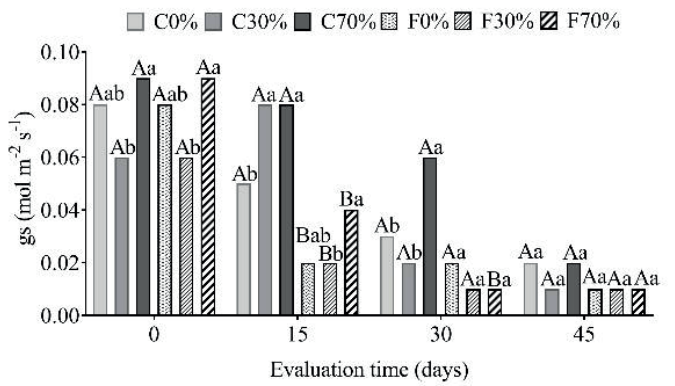

Figure 3. Photosynthetic rate (a.1, a.2), leaf transpiration (b.1, b.2) and stomatal conductance (c.1, c.2) in Campomanesia xanthocarpa Berg. seedlings according to evaluation period, hydric regime (C: control; F: flooding) and shading (0\%; 30\%, and 70\%). Equal uppercase letters do not differ from each other for regime at each level of time and shading by the Bonferroni t-test ( $p \geq 0.05)$. Equal lowercase letters do not differ from each other for shading at each time level and regime, by Tukey's test $(p \geq 0,05)$. 
Leaf transpiration decreased linearly during evaluation times for control plants under $0 \%$ (full sun) and $30 \%$ shades. The other treatments presented a minimal transpiration at 30 days. The flooding provided the lowest transpiration, which was smaller under shading (Figure 3b.1 and 3b.2). These results corroborate the conditions of temperature and relative humidity of the cultivation environment, since under shading, the temperature is lower and the $\mathrm{RH}$ is higher, which favors the lower transpiration intensity.

The flood influenced the stomatal conductance negatively, more specifically at 15 days, where it was lower in all the shaded conditions. However, $0 \%$ and $30 \%$ shades for flooded plants from 30 days were similar to the control, but under $70 \%$, this similarity just occurred at 45 days where there was no difference for any treatment (Figure 3c.1 and 3c.2).

According to Kozlowski (1997), many woody species under flooding present reductions in the photosynthetic rate accompanied by a decrease in stomatal conductance as observed with C. xanthocarpa seedlings in this experiment. In addition, there is also the general reduction in plant transpiration for all the treatments. The factors involved in the restriction of plant photosynthesis may be related to stomata or not (H. B. Li, Chen, \& Li, 2006; Seemann \& Sharkey, 1986; Meyer \& Kouchkovsky, 1993). When related to stomata, these factors cause a limiting effect on photosynthesis in a short term (Satoh, Smith, \& Fork, 1983), as observed for stomatal conductance at 15 days. On the other hand, when factors are not related, the effect is the time prolongation for stress.
The decrease in stomatal conductance under flood can be attributed to the lower permeability and hydraulic conductivity of the root under anaerobic soil conditions. Flooding may also induce stomatal closure (Pezeshki, 2001). Otherwise, under stressful conditions the decrease in gs can be associated to an adaptive behavior since it confers reduction in water loss caused by transpiration, as well as $\mathrm{CO} 2$ diffusion resistance, which is harmful to photosynthetic production (Abiko et al., 2012; Chaves, Flexas, \& Pinheiro, 2009; Yan et al., 2012). Considering these factors, when analyzing gs and $\mathrm{E}$ responses, we observed that there was a direct relation in $\mathrm{C}$. xanthocarpa plants and then the effect on gs reduction seems to be an adaptive reaction of this species.

The internal $\mathrm{CO} 2$ concentration decreased linearly in plants under $30 \%$ shade, with maximum point at 25 days under $70 \%$ and it did not vary significantly under $0 \%$ (overall mean of $275.83 \mu \mathrm{mol}$ mol-1 of CO2) it being larger than the other shadings at 45 days (Figure 4a). The control plants had a maximum point around 20 days and this treatment was superior if compared to flooded seedlings, except for 45 days, when the inversion occurred, resulting in higher values for flooding (Figure 4b). In addition, $\mathrm{Ci}$ in the control plants under full sun was higher than shaded contrasting that in the seedlings flooded the smaller Ci was under 30\% shading (Figure 4c). Lower $\mathrm{Ci}$ in flooded plants is related to lower stomatal conductance which resulted in lower photosynthetic rate and that control plants under shading tend to have lower $\mathrm{Ci}$ and higher photosynthetic rate, proving that shading is a preferential condition for C. xanthocarpa. 
(a)

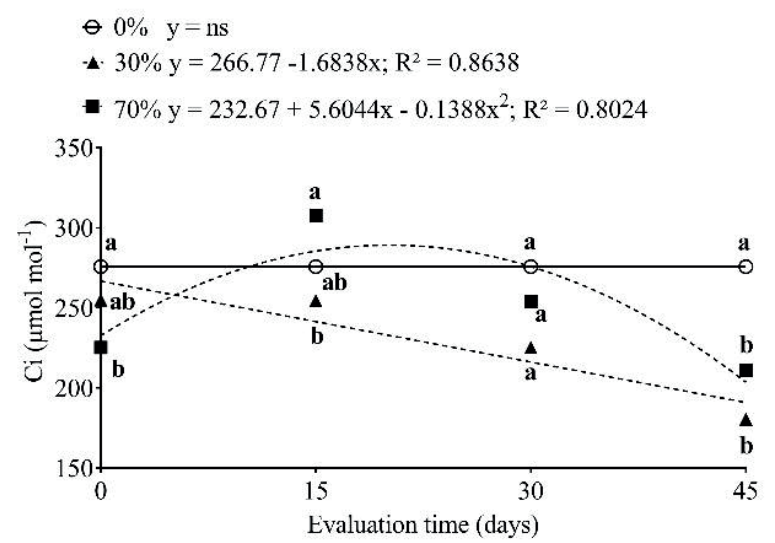

(b)

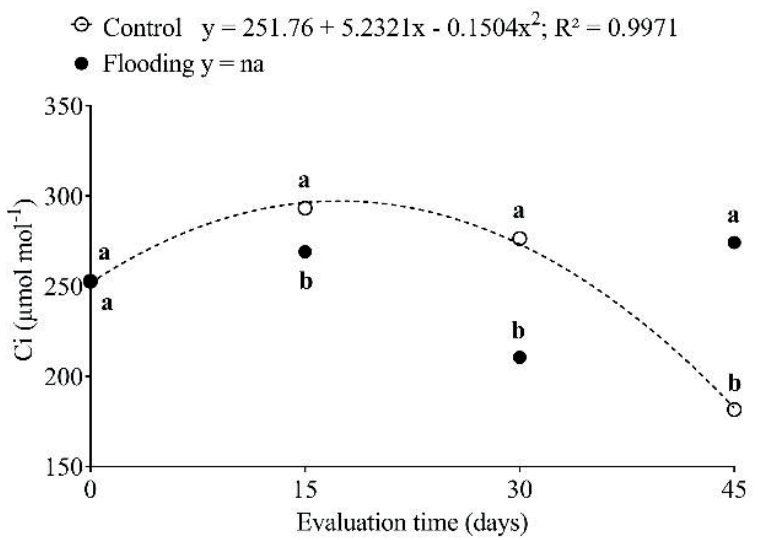

(c)

Control [ Flooding

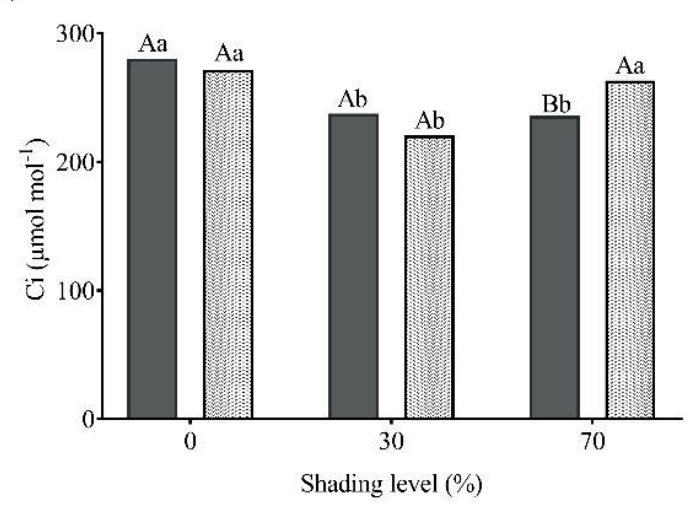

Figure 4. Internal carbon dioxide in Campomanesia xanthocarpa Berg seedlings. (a), hydric regime (control and flooding) and evaluation period (b), where the same lowercase letters do not differ according to the Tukey test $(p \geq 0.05)$ for shading $(0,30$, and 70\%) and for regime by the test of t of Bonferroni $(p \geq 0.05)$. Hydric regime and shading (c), where upper case letters do not differ from each other for regime at each shading level by the Bonferroni t-test $(p \geq 0.05)$ and lowercase letters for each shading by Tukey test $(p \geq 0.05)$. ns = not significant; na = not adjusted

The shading influenced the control treatments significantly, showing higher $\mathrm{A} / \mathrm{Ci}$ values for the highest shadow intensity, which overpassed the initial averages at 45 days. The flooding conditions had a bad effect on $\mathrm{A} / \mathrm{Ci}$, presenting no differences among the shading levels from the 15 days of evaluation (Figure 5 b. 1 and5

b.2). Thus, we concluded that shading conditions did not mitigate the stressful effect of flooding on $\mathrm{A} / \mathrm{Ci}$. 
(a.1)

$\theta \mathrm{C} 0 \% \quad \mathrm{y}=0.0195-0.0008 \mathrm{x}+0.00001 \mathrm{x}^{2} ; \mathrm{R}^{2}=0.9677$

$\triangle \mathrm{C} 30 \% \mathrm{y}=0.0204-0.0005 \mathrm{x}+0.000007 \mathrm{x}^{2} ; \mathrm{R}^{2}=0.9304$

曰 $\mathrm{C} 70 \% \mathrm{y}=0.0265-0.0012 \mathrm{x}+0.00003 \mathrm{x}^{2} ; \mathrm{R}^{2}=0.9742$

- $\mathrm{F} 0 \% \quad \mathrm{y}=0.0193-0.0007 \mathrm{x}+0.000007 \mathrm{x}^{2} ; \mathrm{R}^{2}=0.9282$

- $\mathrm{F} 30 \% \mathrm{y}=0.0194-0.0007 \mathrm{x}+0.000009 \mathrm{x}^{2} ; \mathrm{R}^{2}=0.9354$

- $F 70 \% y=0.0261-0.0011 x+0.00001 x^{2} ; R^{2}=0.9503$

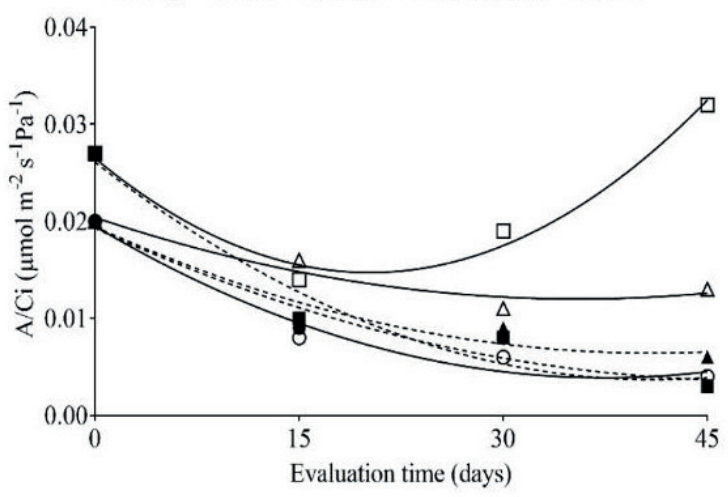

(a.2)

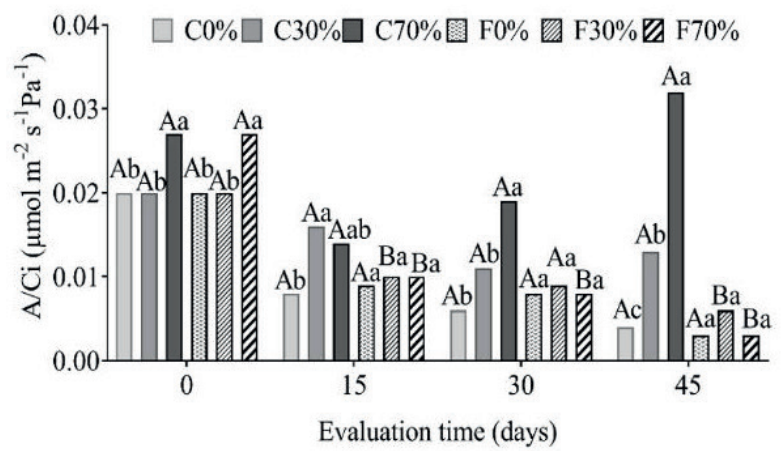

Figure 5. Carboxylation efficiency of Rubisco (a.1, a.2) in Campomanesia xanthocarpa Berg seedlings according to evaluation period, hydric regime (C: control; F: flooding) and shading ( $0 \%$, $30 \%$, and $70 \%$ ). Equal uppercase letters do not differ from each other for regime at each level of time and shading by the Bonferroni t-test $(p \geq 0.05)$. Equal lowercase letters do not differ from each other for shading at each time level and regime, by Tukey's test $(p \geq 0.05)$. ns = not significant; na = not adjusted.

There were differences for the regimes only under $70 \%$ shading, so that the flooded seedlings showed greater $\mathrm{Ci}$ compared to the control. There was no difference between $0 \%$ and $70 \%$ of shades for control seedlings, being greater than $30 \%$. The highest values for $\mathrm{Ci}$ for flooded plants in $70 \%$ of shading justify the lowest photosynthetic rates, and the lowest efficiency for carboxylation of rubisco (A/Ci) at the end of the evaluations. In addition, the $\mathrm{A} / \mathrm{Ci}$ values can be caused by the lack of $\mathrm{O} 2$ in the substrate, damaging the photosynthetic apparatus of seedlings exposed to flood, which it may compromise and reduce the rubisco activity (Flexas et al., 2006).
The water potential was influenced by the single effect of water regime and the interaction between times and shadings. Plants under flood conditions had more negative values than controls (Figure 6a). The lowest value occurred at the initial time ( 0 days) under full sun. Along the experimental period, the three shading levels resulted in linear positive responses for this variable. Plants under $0 \%$ shade were lower at the beginning and at 30 days in relation to $70 \%$ shade (Figure $6 b$ ). 
(a)

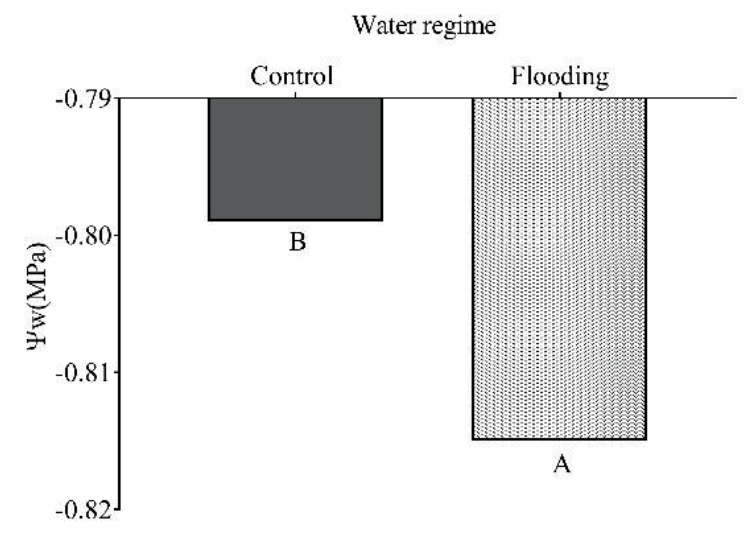

(b)

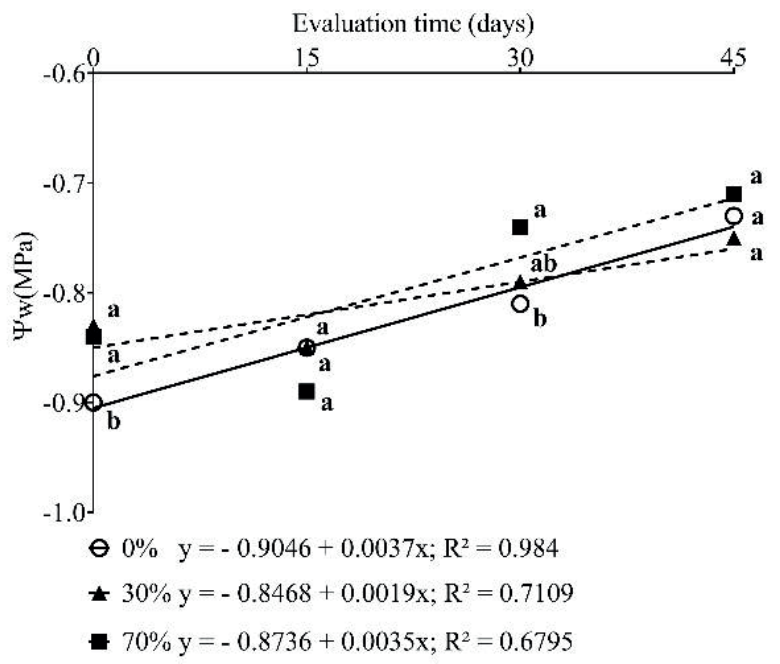

Figure 6. Water potential in Campomanesia xanthocarpa Berg seedlings according to hydric regime (a), where means followed by distinct letters differ from each other by the Bonferroni t-test $(p \geq 0.05)$, hydric regime and evaluation time (b), where the same lowercase letters do not differ from each other for shading by Tukey's test $(p \geq 0.05)$ in each evaluation period.

As a general consideration, it was possible to observe that the sum of flooding and $70 \%$ of shading conferred a stressful condition to C. xanthocarpa, however, this species demonstrated in several aspects the physiological plasticity tendency with adaptive responses to the conditions established in this study. Torezan (2002) observed this tolerance also in the region study, highlighting the composition and structure of the forest in hydromorphic soil, with one of the main species being Myrtaceae. The conclusions corroborate with those of this work, whose plants presented more expressive reduction of metabolism, as a strategy of tolerance to temporary flooding and adjustment along the evaluation times. For shading, C. xanthocarpa was classified as secondary (Vaccaro, Longhi, \& Brena, 1999) or climatic (Lorenzi, 2002), which it may explain its higher performance under the medium shadow level (30\%).
The information obtained with our results point to a possible indication of the use of $C$. xanthocarpa for the recovery of riparian forests with seasonal flooding, once even showing sensitivity under this condition, the species showed adjustment or recovery to stress. In addition, a certain condition of shading is necessary for its establishment success. However, new works must be carried out for a longer period of evaluation in order to verify the effectiveness of adjustment and recovery of the seedlings to the tested conditions.

We emphasize that, although the seedlings have undergone a period of 10 days of acclimatization to light environments, we believe that this time for C. xanthocarpa was not enough, once the control seedlings presented changes in photosynthetic metabolism that characterized adjustments 
to the environments of cultivation and that the temperature and relative humidity during the experiment was within the range of the natural environment of the species.

\section{Factorial analysis (FA)}

The first two factors with eigenvalues higher than $1(\lambda i>1)$ (Kaiser, 1958), resulting from the factor analysis (FA) explained together $68.66 \%$ of the total variance of experimental data, it being the factor 1 (F1) and factor 2 (F2) responsible for $51.26 \%$ and $17.40 \%$, respectively.

The Figure 7 shows the eigenvectors of the variables in the factorial plane. We adopted eigenvectors with factor loadings $>0.70$ as significance standard. Thus, $F 1$ is represented by A (0.966); gs (0.917); NL (0.894); A/Ci (0.878); and $\mathrm{E}(0.863)$, and $\mathrm{F} 2$ represented mainly by $\mathrm{Ci}$ (0.961).

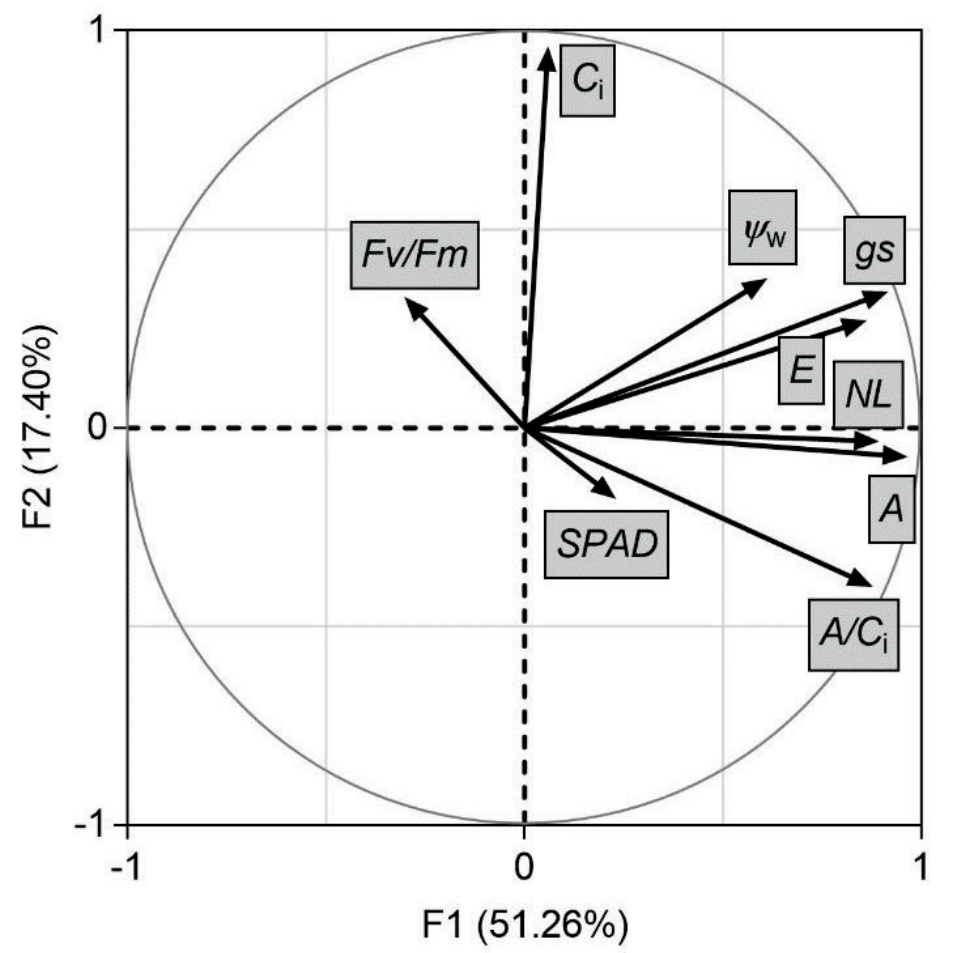

Figure 7. Factoranalysis loading plot(F1 and F2 axes) of the measured parameters in Campomanesia xanthocarpa Berg seedlings according to evaluation period $(0,15,30$, and 45 days) hydric regime (C: control; F: flooding) and shading (0\%,30\%, and 70\%). Chlorophyll index (SPAD); number of leaves (NL); maximal photochemical efficiency of PSII (Fv/Fm); photosynthetic rate (A); leaf transpiration (E); stomatal conductance (gs); internal carbon dioxide (Ci); carboxylation efficiency of Rubisco (A/ Ci); water potential $\left(\Psi_{\mathrm{W}}\right)$. 
Factor analysis helped to understand some results, such as the relation between photosynthetic rate and stomatal parameters. F1 showed that $A$ and gs were the two variables that had contributed the most to the behavior of experimental data. In addition, A/Ci was also directly related to both, and $\mathrm{Ci}$ was not significant on this axis, then we believe that despite the limitation in the photosynthetic rate, with an increase in $\mathrm{Ci}$, it must occur in a short term, which decreases the time of stress state, demonstrating the ability of $C$. xanthocarpa in the metabolic adjustment under flooding stress.

Another important $\mathrm{AF}$ result is the proximity between $\mathrm{A}$ and $\mathrm{NL}$, which although $\mathrm{NL}$ may be considered a less specific parameter, especially when it comes to not dominated native species, there was here a direct relation with a similar contribution to the photosynthetic rate in explaining the total variance of data.

\section{Conclusions}

Campomanesia xanthocarpa was sensitive to flood conditions and full sun and high level of shading (70\%) in a short period (15 days) with damage to the photosynthetic apparatus and reduction in the efficiency of the photochemical process. However, it presented responses for possible adaptation over the period of exposure to these conditions. Results from the application of multivariate factor analysis allowed concluding that the direct relationship between photosynthetic rate and stomatal conductance formed the main factor of metabolic adjustments in the tolerance of C. xanthocarpa to flooding and high shading intensity.

\section{Acknowledgement}

The authors acknowledge the research incentive received from the Federal University of Grande Dourados (UFGD) and the financial support from National Council for Scientific and Technological Development (CNPq) and The Coordination for the Improvement of Higher Education Personnel (CAPES).

\section{References}

Abiko, T., Kotuia, L., Shiono, K., Malik, A., Colmer, T. D., \& Nakazono, M. (2012). Enhanced formation of aerenchyma and induction of a barrier to radial oxygen loss in adventitious roots of Zea nicaraguensis contribute to its waterlogging tolerance as compared with maize. Plant Cell Environmental, 35(9), 1618-1630. doi: 10. 1111/j.1365-3040.2012.02513.x

Adams, W.W., Zarter, C. R., Ebbert, V., \&DemmigAdams, B. (2004). Photoprotective strategies of overwintering evergreens. Bioscience, 54(1), 41-49. doi: 10.1641/00 06-3568(2004)054[0041:PSOOE]2.0. $\mathrm{CO} ; 2$

Addınsoft. XLSTAT statistical and data analysis solution (version 2019). Retrieved from: https://www.xlstat. com

Ajalla, A. C. A., Vieira, M. C., Volpe, E., \& Zárate, N. A. H. (2014). Crescimento de mudas de Campomanesia adamantium (Cambess.) O. Berg (guavira), submetidas a três níveis de sombreamento e substratos. Revista Brasileira de Fruticultura, 36(2), 449-458. doi: 10.1590/0100-2945-196/13

Baker, N. R. (2008). Chlorophyll fluorescence: a probe of photosynthesis in vivo. 
Annual Review Plant Biology, 59(1), 89113. doi: 10.1146/annurev.arplant.59.03 2607.092759

Baker, N. R., \& Rosenqvist, E. (2004). Applications of chlorophyll fluorescence can improve crop production strategies: an examination of future possibilities. Journal Experimental of Botany, 55(403), 1607-1621. doi: 10.1093/jxb/erh196

Bartieres, E. M. M., Scalon, S. P. Q., Dresch, D. M., Cardoso, E. A. S., Jesus, M. V., \& Pereira, Z. V. (2020). Shading as a means of mitigating water deficit in seedlings of Campomanesia xanthocarpa (Mart.) O. Berg. Notulae Botanicae Horti Agrobotanici Cluj-Napoca, 48(1), 234244. doi: 10.15835/nbha48111720

Burritt, D. J., \& Mackenzie, S. (2003). Antioxidant metabolism during acclimation of Begonia $x$ erythrophylla to high light levels. Annals of Botany, 91(7), 783-794. doi: 10.1093/ aob/mcg076

Calatayud, A., Roca, D., \& Martínez, P. F. (2006). Spatial-temporal variations in rose leaves under water stress conditions studied by chlorophyll fluorescence imaging. Plant Physiology and Biochemistry, 44(10), 564573. doi: 10.1016/j.plaphy.2006.09.015

Chaves, M. M., Flexas, J., \& Pinheiro, C. (2009). Photosynthesis under drought and salt stress: regulation mechanisms from whole plant to cell. Annals of Botany, 103(4), 551-560. doi: 10.1093/aob/men125

Cremon, T., Scalon, S. P. Q., Rosa, D. B. C. J., \& Dresch, D. M. (2020). How does Copaifera langsdorffii respond to flooding under different irradiance levels? Plant Biosystems-An International Journal Dealing with all
Aspects of Plant Biology, 1-11. doi: 10.1080/11263504.2020.1832604

Deng, Z., Cao, S., Tang, Y., Lu, W., \& Zhang, R. (2001). Comparison on some aspects of photosynthetic declination of wild rice and cultivated rices. Acta Agronomica Sinica, 27(4), 453-459.

Duarte, W. F., Dias, D. R., Melo Pereira, G. V. de, Gervásio, I. M., \& Schwan, R. F. (2009). Indigenous and inoculated yeast fermentation of gabiroba (Campomanesia pubescens) pulp for fruit wine production. Journal Indian Microbiology and Biotechnology, 36(4), 557-569. doi: 10. 1007/s10295-009-0526-y

Fan, X. L., Zhang, Z. S., Gao, H. Y., Yang, C., Liu, M. J., Li, Y., \& Li, P. (2014). Photoinhibition-like damage to the photosynthetic apparatus in plant leaves induced by submergence treatment in the dark. PloS One, 9(2), 16331641. doi: 10.1371/journal.pone.0089067

Ferreira, D. F. (2014). Sisvar: a guide for its bootstrap procedures in multiple comparisons. Ciência e Agrotecnologia, 358(2), 109-112. doi: 10.1590/S141370542014000200001

Flexas, J., Ribas-Carbó, M., Bota, J., Galmés, J., Henkle, M., Martínez-Cañellas, S., \& Medrano, H. (2006). Decreased Rubisco activity during water stress is not induced by decreased relative water content but related to conditions of low stomatal conductance and chloroplast $\mathrm{CO}_{2}$ concentration. New Phytology, 172(1), 73-82. doi: 10.1111/j.1469-8137. 2006.01794.x

GraphPad. GraphPad Prism Software (version 7.00 for Windows). Retrieved from: www. graphpad.com 
Kaiser, H. F. (1958). The varimax criterion for analytic rotation in fator analysis. Psychometrika, 23(3), 187-200. doi: 10. 1007/BF02289233

Khurana, S., Venkataraman, K., \& Hollingsworth, A. (2013) Polyphenols: benefits to the cardiovascular system in health and in aging. Nutrients, 5(10), 3779-3827. doi: 10.3390/nu5103779

Kozlowski, T. (1997). Responses of woody plants to flooding and salinity. Tree Physiology, 17(7), 1-29. doi: 10.1093/tree phys/17.7.490

Krupek, R.A.,\&Lima, A.G. (2012). Variation inleaf structure of guabiroba (Campomanesia xanthocarpa Berg.) under different lightning conditions in a remnant of Araucaria Forestry. Ambiência, 8(2), 293305. doi: 10.5777/ambiencia.2012.02.05

Lemos-Filho, J. P. (2000). Photoinhibition in three "cerrado" species (Annona crassfolia, Eugenia dysenterica e Campomanesia adamantium), in the dry and rainy seasons. Brazilian Journal of Botany, 23(1), 45-50. doi: 10.1590/S010084042000000100005

Lescano, C. H., Oliveira, I. P., Zaminelli, T., Baldivia, D. D., Silva, L. R., Napolitano, M.,... Sanjinez-Argandoña, E. J. (2016). Campomanesia adamantium peel extract in antidiarrheal activity: the ability of inhibition of heat-stable enterotoxin by polyphenols. PloS One, 11(10), 1-15. doi: 10.1371/journal.pone.0165208

Li, H. B., Chen, W. F., \& Li, Q. Y. (2006). Responses of rice leaf photosynthetic parameters to light intensity under $\mathrm{NaCl}$ stress. Chinese Journal of Applied Ecology, 17(9), 15881592.
Li, S., Yang, W., Yang, T., Chen, Y., \& Ni, W. (2015). Effects of cadmium stress on leaf chlorophyll fluorescence and photosynthesis of Elsholtzia argyi - a cadmiumaccumulating plant. International Journal of Phytoremediation, 17(1), 8592. doi: 10.1080/15226514.2013.828020

Lorenzi, H. (2002). Árvores brasileiras: manual de identificação e cultivo de plantas arbóreas do Brasil. Nova Odessa, SP: Plantarum.

Lorenzi, H. (2008). Árvores brasileiras: manual de identificação e cultivo de plantas arbóreas nativas do Brasil. Nova Odessa, SP: Plantarum.

Lüttge, U. (2004). Ecophysiology of crassulacean acid metabolism (CAM). Annals of Botany, 93(6), 629-652. doi: 10.1093/aob/mch087

Marschner, P. (2012). Mineral nutrition of higher plants (3nd ed.). San Diego: Academic Press.

Meyer, S., \& Kouchkovsky, Y. (1993). Electron transport, Photosystem-2 reaction centers and chlorophyll-protein complexes of thylakoids of drought resistant and sensitive Lupin piants. Photosynthetic Research, 37(1), 49-60. doi: 10.1007/BF02185438

Ministério do Meio Ambiente (2018). Plano de ação para prevenção e controle do desmatamento e das queimadas no Cerrado (PPCerrado) e plano de ação para prevenção e controle do desmatamento na Amazônia Legal (PPCDAm): fase 20162020. Brasília: MMA.

Otero, J. S., Hirsch, G. E., Klafke, J. Z., Porto, F. G., Almeida, A. S., Nascimento, S.,... Viecilli, P. R. N. (2017). Inhibitory effect of 
Campomanesia xanthocarpa in platelet aggregation: comparison and synergism with acetylsalicylic acid. Thrombosis Research, 154(1), 2-49. doi: 10.1016/j. thromres.2017.03.020

Pezeshki, S. R. (2001). Wetland plant responses to soil flooding. Environmental Experimental of Botany, 46(3), 299-312. doi: 10.1016/S0098-8472(01)00107-1

Pimenta, J. A. (1998). Estudo populacional de Campomanesia xanthocarpa O. Berg (Myrtaceae) no parque estadual Mata dos Godoy, Londrina, PR. Tese de doutorado, Universidade de Campinas, Campinas, SP, Brasil.

Posada-Casierra, F., \& Cutler, J. (2017). Photosystem II fluorescence and growth in cabbage plants (Brassica oleracea var. capitata) grown under waterlogging stress. Revista U.D.C.A Actualidad \& Divulgación Científica, 20(2), 321-328. doi: 10.31910/rudca.v20.n2.2017.390

Satoh, K., Smith, C. M., \& Fork, D. C. (1983). Effects of salinity on primary processes of photosynthesis in the red alga. Porphyra perforata. Plant Physiology, 73(3), 643647. doi: 10.1104/pp.73.3.643

Seemann, J. R., \& Sharkey, T. D. (1986). Salinity and nitrogen effects on photosynthesis, ribulose-1, 5-bisphosphate carboxylase and metabolite pool sizes in Phaseolus vulgaris L. Plant Physiology, 82(2), 555560. doi: 10.1104/pp.82.2.555

Souza, J. C., Piccinelli, A. C., Aquino, D. F. S., Souza, V. V., Schmitz, W. O., Traesel, G. K.,... Arena, A. C. (2017). Toxicological analysis and antihyperalgesic, antidepressant, and anti-inflammatory effects of
Campomanesia adamantium fruit barks. Nutritional Neuroscience, 20(1), 23-31. doi: 10.1179/1476830 514Y.0000000145

Torezan, J. M. (2002). Nota sobre a vegetação da bacia do rio Tibagi. In M. E. Medri, E. Bianchini, A. O. Shibatta, \& J. A. Pimenta (Eds.), A bacia do rio Tibagi (pp. 103-107). Londrina, PR: Editora dos Editores.

Vaccaro, S., Longhi, S. J., \& Brena, D. A. (1999). Floristic composition aspects and forest successional categories of three subsers in a deciduous seasonal forest, in the district of Santa Tereza RS. Ciência Florestal, 9(1), 1-18. doi: 10. 5902/19805098360

Viecili, P. R. N., Borges, D. O., Kirsten, K., Malhêiros, J., Viecili, E., Melo, R. D.,... Klafke, J. Z. (2014). Effects of Campomanesia xanthocarpa on inflammatory processes, oxidative stress, endothelial dysfunction and lipid biomarkers in hypercholesterolemic individuals. Atherosclerosis, 234(1), 85-92. doi: 10. 1016/j.atherosclerosis.2014.02.010

Yan, K., Chen, P., Shao, H., Zhao, S., Zhang, L., Zhang, L.,... Sun, J. (2012). Responses of photosynthesis and photosystem II to higher temperature and salt stress in sorghum. Journal of Agronomy Crop Science, 198(3), 218-226. doi: 10.1111/j.1439-037X.2011.00498.x

Zhao, H. F., Zhao, Y., Zhang, C., Tao, X., \& Xu, $X$. N. (2014). Growth, leaf gas exchange, and chlorophyll fluorescence responses of two cultivars of Salix integra Thunb to waterlogging stress. Journal Agricultural Science and Technology, 16(1), 137-149. 
